Article

\title{
Sikokianin D, A New C-3/C-3"-Biflavanone from the Roots of Wikstroemia indica
}

\section{Jie Li *, Lin-Yan Lu, Ling-Hui Zeng, Chong Zhang, Jia-Lei Hu and Xiang-Rong Li *}

School of Medicine, Zhejiang University City College, No. 48 Huzhou Road, Hangzhou 310015, Zhejiang, China

* Authors to whom correspondence should be addressed; E-Mails: lijie@zucc.edu.cn (J.L.); lixr@zucc.edu.cn (X.-R.L.).

Received: 28 April 2012; in revised form: 15 June 2012 / Accepted: 19 June 2012 /

Published: 26 June 2012

\begin{abstract}
A new 3,3"-biflavanone, sikokianin D (1), was isolated from the roots of Wikstroemia indica, together with two known compounds. Their structures were elucidated by chemical evidence and spectral analyses, including HR-ESI-MS, and 1D- and 2D-NMR techniques.
\end{abstract}

Keywords: Wikstroemia indica; sikokianin D; C-3/C-3"-biflavanone

\section{Introduction}

Wikstroemia indica (Linn.) C. A. Mey., a shrub of the Thymelaeaceae family, is wildely distributed in the southeast of China. Known as Liaogewang, it has long been used as a folk medicine in southern China for treating arthritis, tuberculosis, syphilis and pertussis [1]. Moreover, W. indica has antifungal, anti-inflammatory, anti-cancer, antiviral and antimalarial effects [2-7]. The chemical constituents of the roots have been investigated previously, leading to the identification of groups of flavonoid, coumarin and lignan compounds [2-9]. In previous paper [10], we have reported several C-3/C-3"-biflavanones from the roots of Stellera chamaejasme L. (Thymelaeaceae) collected in Yunnan. C-3/C-3"-Biflavanones have been shown to exhibit a wide range of pharmacological activities, such as antibacterial, anti-inflammatory, antimalarial, and antitumor activities [4,11-14]. In connection with these interesting biflavanones, we examined the chemical constituents of other Thymelaeaceae plants and one new C-3/C-3"-biflavanone, sikokianin D (1), together with two known compounds, namely sikokianin B (2) 
and sikokianin A (3) (Figure 1) was isolated from the roots of Wikstroemia indica. This paper describes the isolation and structure elucidation of these compounds.

Figure 1. Chemical Structures of 1-3.

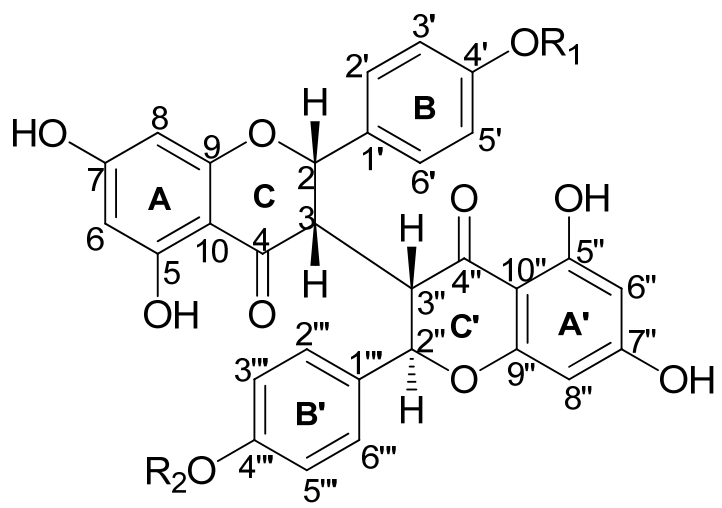

$1 \mathrm{R}_{1}=\mathrm{CH}_{3}, \mathrm{R}_{2}=\mathrm{H}$ or its antipode

$2 \mathrm{R}_{1}=\mathrm{H}, \mathrm{R}_{2}=\mathrm{CH}_{3}$ or its antipode<smiles>COc1ccc([C@H]2Oc3cc(O)cc(O)c3C(=O)[C@H]2[C@H]2C(=O)c3c(O)cc(O)cc3O[C@H]2c2ccc(O)cc2)cc1</smiles>

3 or its antipode

\section{Results and Discussion}

Compound 1 was obtained as a pale yellow amorphous powder with optical activity $\left([\alpha]_{D}^{20}:+231\right)$. The HR-ESI-MS of 1 exhibited a quasi-molecular-ion peak $\left([\mathrm{M}+\mathrm{H}]^{+}\right)$at $m / z 557.1442$ (calc. 557.1448), corresponding to the molecular formula $\mathrm{C}_{31} \mathrm{H}_{24} \mathrm{O}_{10}$. Moreover, this compound showed positive reaction with HCl-Mg reagent, indicating that it is a flavonoid. The ${ }^{1} \mathrm{H}-\mathrm{NMR}$ spectrum of 1 (Table 1) displayed signals of one methoxyl group $\left(\delta_{\mathrm{H}} 3.79, \mathrm{~s}, 3 \mathrm{H}\right)$, two H-atoms corresponding to $\mathrm{H}-2\left(\delta_{\mathrm{H}} 5.57,1 \mathrm{H}, \mathrm{d}\right.$, $J=5.0 \mathrm{~Hz})$ and $\mathrm{H}-2 "\left(\delta_{\mathrm{H}} 5.19,1 \mathrm{H}, \mathrm{d}, J=9.5 \mathrm{~Hz}\right)$, and two H-atoms corresponding to $\mathrm{H}-3\left(\delta_{\mathrm{H}} 3.19,1 \mathrm{H}\right.$, br s) and $\mathrm{H}-3 "\left(\delta_{\mathrm{H}} 3.26,1 \mathrm{H}, \mathrm{dd}, J=9.5,3.0 \mathrm{~Hz}\right)$ at the rings $\mathrm{C}$ and $\mathrm{C}^{\prime}$ of the biflavanone. In the ${ }^{1} \mathrm{H}$ - and ${ }^{13} \mathrm{C}-\mathrm{NMR}$ established by ${ }^{1} \mathrm{H}-{ }^{1} \mathrm{H}$ COSY and HMQC experiments (Table 1), the spectra showed its structural fragments to include two sets of typical 5,7-dioxygenated A rings $\left(\delta_{\mathrm{H}} 5.74,5.77\right.$, each $1 \mathrm{H}, \mathrm{d}$, $J=2.0 \mathrm{~Hz} ; \delta_{\mathrm{H}} 5.78,5.98$, each $\left.1 \mathrm{H}, \mathrm{d}, J=2.0 \mathrm{~Hz}\right)$, and two sets of para-oxygenated B rings $\left(\delta_{\mathrm{H}} 7.22\right.$, 6.90, each $2 \mathrm{H}, \mathrm{d}, J=8.5 \mathrm{~Hz} ; \delta_{\mathrm{H}} 6.93,6.63$, each $2 \mathrm{H}, \mathrm{d}, J=8.5 \mathrm{~Hz}$ ). From the ${ }^{13} \mathrm{C}-\mathrm{NMR}$ data (Table 1), two carbonyl groups $\left(\delta_{\mathrm{C}} 198.5,196.1\right)$ were also observed. These structural fragments were connected to form the given carbon framework of $\mathbf{1}$ as a dimer of flavanonol derivatives. The partial (-CH-CH-CH$\mathrm{CH}-$ ) structure inferred from the ${ }^{1} \mathrm{H}-{ }^{1} \mathrm{H}$ COSY spectrum (bold line in Figure 2) suggested that the linkage of the two flavanones was possible only at the C-3 and C-3" positions, which was supported by the comparison of the ${ }^{1} \mathrm{H}$ - and ${ }^{13} \mathrm{C}$-NMR data of 1 with those of known 3,3"-biflavanones [4,6,8,10], and further confirmed by the HMBC correlations of $\mathrm{H}-2\left(\delta_{\mathrm{H}} 5.57\right)$ with $\mathrm{C}-3$ " $\left(\delta_{\mathrm{C}} 51.0\right)$. The B ring could be located at C-2, based on the observation of the clear cross-peaks of H-2' and H-6' $\left(\delta_{\mathrm{H}} 7.22\right)$ with $\mathrm{C}-2$ $\left(\delta_{\mathrm{C}} 81.2\right)$. In the same way, linkage of the $\mathrm{B}^{\prime}$ ring to $\mathrm{C}-2$ " of the $\mathrm{C}^{\prime}$ ring was deduced by the correlations of H-2"'and H-6"' $\left(\delta_{\mathrm{H}} 6.93\right)$ with C-2" $\left(\delta_{\mathrm{C}} 83.3\right)$. The HMBC cross-peak between the methoxyl group and $\mathrm{C}-4$ ' on the $\mathrm{B}$ ring indicated that the methoxyl group was connected to $\mathrm{C}-4$ '.

The stereochemistry at the $\mathrm{C}-2 / \mathrm{C}-3$ and $\mathrm{C}-2 " / \mathrm{C}-3 "$ positions in $\mathbf{1}$ was determined as cis-trans by comparison of the $J$ values $\left(J_{\mathrm{H}-2}=5.0 \mathrm{~Hz}\right.$ and $\left.J_{\mathrm{H}-2 "}=9.5 \mathrm{~Hz}\right)$ with those of the known 3,3"-biflavanones. The key NOESY correlations between H-2" $\left(\delta_{\mathrm{H}} 5.19\right)$ with H-2'(H-6') $\left(\delta_{\mathrm{H}} 7.22\right)$ 
further confirmed the conclusion above. The relative stereochemistry of compound $\mathbf{1}$ was confirmed as shown in Figure 1 and the compound named sikokianin D.

Compound 2 was first reported as sikokianin B of which the location of $\mathrm{MeO}$ group was unsettled [8], and the exact configuration was elucidated by Nunome [4]. Sikokianin B and sikokianin C were determined by comparing their ${ }^{1} \mathrm{H}$ - and ${ }^{13} \mathrm{C}-\mathrm{NMR}$ and MS data with published values.

Table 1. NMR data of sikokianin $\mathrm{D}(\mathbf{1})$ in $\mathrm{CD}_{3} \mathrm{OD}\left(500 \mathrm{MHz}\right.$ for ${ }^{1} \mathrm{H}, 125 \mathrm{MHz}$ for $\left.{ }^{13} \mathrm{C}\right)$.

\begin{tabular}{|c|c|c|}
\hline No. & $\delta_{\mathrm{H}}$ Mult $(J=\mathrm{Hz})$ & $\delta_{\mathrm{C}}$ \\
\hline 2 & $5.57 \mathrm{~d}(5.0)$ & $81.2 \mathrm{~d}$ \\
\hline 3 & $3.19 \mathrm{br} \mathrm{s}$ & $49.3 \mathrm{~d}$ \\
\hline 4 & - & $198.5 \mathrm{~s}$ \\
\hline 5 & - & $165.0 \mathrm{~s}$ \\
\hline 6 & $5.74 \mathrm{~d}(2.0)$ & $96.0 \mathrm{~d}$ \\
\hline 7 & - & $168.1 \mathrm{~s}$ \\
\hline 8 & $5.77 \mathrm{~d}(2.0)$ & $97.0 \mathrm{~d}$ \\
\hline 9 & - & $165.0 \mathrm{~s}$ \\
\hline 10 & - & $103.6 \mathrm{~s}$ \\
\hline $1^{\prime}$ & - & $130.0 \mathrm{~s}$ \\
\hline $2^{\prime}$ & $7.22 \mathrm{~d}(8.5)$ & $128.4 \mathrm{~d}$ \\
\hline $3^{\prime}$ & $6.90 \mathrm{~d}(8.5)$ & $114.9 \mathrm{~d}$ \\
\hline $4^{\prime}$ & - & $160.9 \mathrm{~s}$ \\
\hline $5^{\prime}$ & $6.90 \mathrm{~d}(8.5)$ & $114.9 \mathrm{~d}$ \\
\hline $6^{\prime}$ & $7.22 \mathrm{~d}(8.5)$ & $128.4 \mathrm{~d}$ \\
\hline $2^{\prime \prime}$ & $5.19 \mathrm{~d}(9.5)$ & $83.3 \mathrm{~d}$ \\
\hline $3^{\prime \prime}$ & $3.26 \mathrm{dd}(9.5,3.0)$ & $51.0 \mathrm{~d}$ \\
\hline $4^{\prime \prime}$ & - & $196.1 \mathrm{~s}$ \\
\hline $5^{\prime \prime}$ & - & $165.3 \mathrm{~s}$ \\
\hline $6^{\prime \prime}$ & $5.78 \mathrm{~d}(2.0)$ & $97.0 \mathrm{~d}$ \\
\hline $7 "$ & - & $167.9 \mathrm{~s}$ \\
\hline $8^{\prime \prime}$ & $5.98 \mathrm{~d}(2.0)$ & $96.4 \mathrm{~d}$ \\
\hline $9^{\prime \prime}$ & - & $163.9 \mathrm{~s}$ \\
\hline $10^{\prime \prime}$ & - & $105.1 \mathrm{~s}$ \\
\hline $1 " '$ & - & $128.9 \mathrm{~s}$ \\
\hline $2^{\prime \prime \prime}$ & $6.93 \mathrm{~d}(8.5)$ & $130.3 \mathrm{~d}$ \\
\hline $3^{\prime \prime \prime}$ & $6.63 \mathrm{~d}(8.5)$ & $116.1 \mathrm{~d}$ \\
\hline $4 " '$ & - & $158.9 \mathrm{~s}$ \\
\hline $5^{\prime \prime \prime}$ & $6.63 \mathrm{~d}(8.5)$ & $116.1 \mathrm{~d}$ \\
\hline $6^{\prime \prime \prime}$ & $6.93 \mathrm{~d}(8.5)$ & $130.3 \mathrm{~d}$ \\
\hline $4^{\prime}-\mathrm{OCH}_{3}$ & $3.79 \mathrm{~s}$ & $55.7 \mathrm{q}$ \\
\hline
\end{tabular}


Figure 2. Key ${ }^{1} \mathrm{H}-{ }^{1} \mathrm{H}$ COSY and $\mathrm{HMBC}$ correlations of $\mathbf{1}$.

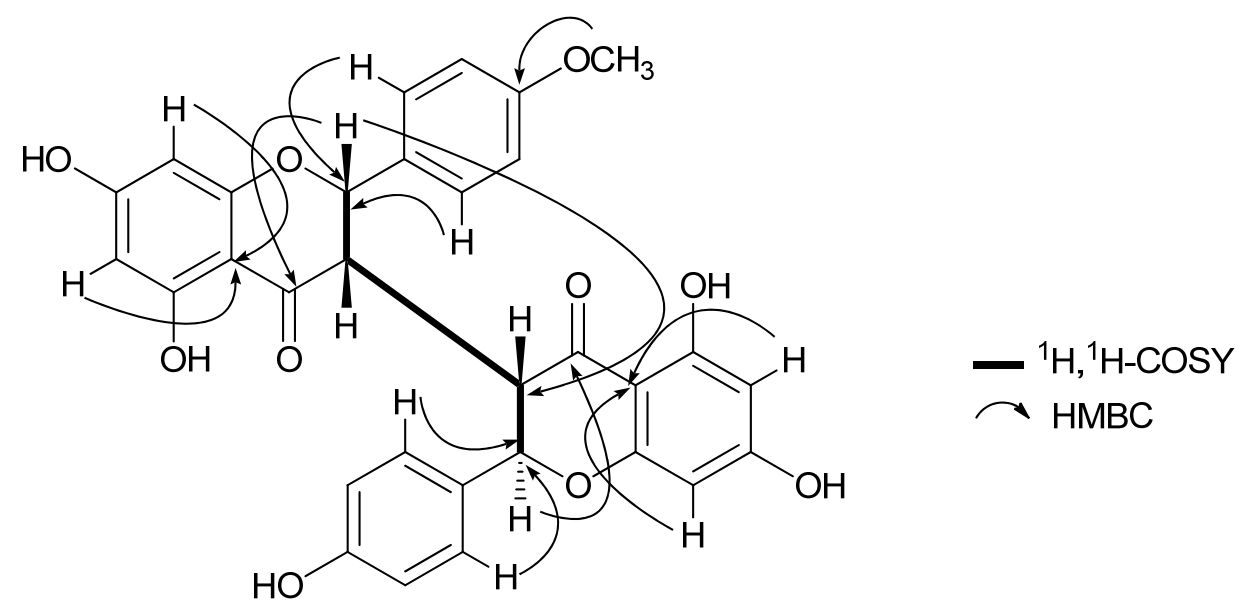

\section{Experimental}

\subsection{General}

Melting points were measured on a Thermal Values analytical microscope and are uncorrected. Optical rotations were recorded on a Perkin-Elmer 341 polarimeter. IR spectra were recorded on a Nicolet FI-IR 200SXY spectrophotomer. The spectra of high resolution-electrospray ionization-mass spectrometry (HR-ESI-MS) were acquired with a Micromass Q-TOF mass spectrometer (Waters Corporation USA). ${ }^{1} \mathrm{H}$ - and ${ }^{13} \mathrm{C}$-NMR spectra were measured in $\mathrm{CD}_{3} \mathrm{OD}$ with TMS as the internal standard on a Bruker DMX-500 NMR instrument. Silica gel $\mathrm{G}_{254}$ and H (Qingdao Sea Chemical Factory, China) were used for TLC and column chromatography, respectively.

\subsection{Plant Material}

The roots of Wikstroemia indica were purchased from a Chinese medicine pharmacy in Guangzhou, China, in September, 2011. The authentication process was carried out by Le Cai (Yunnan University). A voucher specimen was deposited in the Zhejiang University City College.

\subsection{Extraction and Isolation}

Air-dried powder roots $(2.6 \mathrm{~kg})$ of $W$. indica were extracted exhaustively with $95 \%$ aq. EtOH $(9 \mathrm{~L} \times 3)$ at $\mathrm{r}$. t. After concentration in vacuo, a crude extract $(270 \mathrm{~g})$ was obtained, which was suspended in $1 \mathrm{~L} \mathrm{H}_{2} \mathrm{O}$, and the suspension was extracted successively with petroleum ether $(\mathrm{PE}, 1 \mathrm{~L} \times 3)$, EtOAc $(1 \mathrm{~L} \times 3)$, and $\mathrm{BuOH}(1 \mathrm{~L} \times 3)$ to yield $34,110,89 \mathrm{~g}$ fractions, resp. The EtOAc extract was subjected to $\mathrm{CC}$ with $\mathrm{PE} /$ EtOAc gradient system of increasing polarity $(9 / 1 \rightarrow 5 / 5,3600 \mathrm{~mL})$ to give five fractions (Fraction 1-5). Fraction 3 was chromatographed repeatedly over $\mathrm{SiO} 2$ column with $\mathrm{MeOH} / \mathrm{H}_{2} \mathrm{O}$ $(7 / 3 \rightarrow 9 / 1,1,200 \mathrm{~mL})$ to afford 3 (15 mg). Fraction 4 was subjected to MPLC on octadecyl silica gel $(3.5 \times 30 \mathrm{~cm})$ eluting by gradient elution with $\mathrm{MeOH}-\mathrm{H}_{2} \mathrm{O}(5 \mathrm{~mL} / \mathrm{min}$, linear gradient, $50: 50 \rightarrow 90: 10)$ to yield compounds $1(28 \mathrm{mg})$ and $\mathbf{2}(36 \mathrm{mg})$. 
Sikokianin D (1). Yellow amorphous powder, mp 213-215 ${ }^{\circ} \mathrm{C} ;\left([\alpha]_{D}^{20}\right.$ : +231 (c = 0.48, MeOH); IR $\left(\mathrm{KBr}, \mathrm{cm}^{-1}\right)$ : 3362, 1643; ${ }^{1} \mathrm{H}-\mathrm{NMR}$ and ${ }^{13} \mathrm{C}-\mathrm{NMR}$ data, see Table 1; HR-ESI-MS: $\mathrm{m} / \mathrm{z} 557.1442$ $[\mathrm{M}+\mathrm{H}]^{+}$, calcd for $\mathrm{C}_{31} \mathrm{H}_{25} \mathrm{O}_{10}, 557.1448$.

Sikokianin B (2). Yellow amorphous powder. ${ }^{1} \mathrm{H}-\mathrm{NMR}$ : $\delta_{\mathrm{H}} 3.23(1 \mathrm{H}, \mathrm{t}, J=3.5 \mathrm{~Hz}, \mathrm{H}-3), 3.33(1 \mathrm{H}$, dd, $J=9.5,3.0 \mathrm{~Hz}, \mathrm{H}-3 "), 3.76\left(3 \mathrm{H}, \mathrm{s}, \mathrm{OCH}_{3}\right), 5.17$ (1H, d, $\left.J=9 \mathrm{~Hz}, \mathrm{H}-2 "\right), 5.53$ (1H, d, $\left.J=4.5 \mathrm{~Hz}, \mathrm{H}-2\right)$, $5.75(1 \mathrm{H}, \mathrm{d}, J=2.0 \mathrm{~Hz}, \mathrm{H}-6), 5.84(1 \mathrm{H}, \mathrm{d}, J=2.0 \mathrm{~Hz}, \mathrm{H}-8), 5.86$ (1H, d, $J=2.0 \mathrm{~Hz}, \mathrm{H}-6 "), 5.97$ (1H, d, $\left.J=2.0 \mathrm{~Hz}, \mathrm{H}-8^{\prime \prime}\right), 6.74 \sim 7.16(8 \mathrm{H}, \mathrm{m}, \mathrm{H}-\mathrm{Ar})$. HR-ESI-MS: $m / z 557.1446[\mathrm{M}+\mathrm{H}]^{+}$. Spectral data were in accordance with those reported in the literature [4,8], which confirmed that the isolated compound 2 was sikokianin B.

Sikokianin A (3). Yellow amorphous powder. ${ }^{1} \mathrm{H}-\mathrm{NMR}$ : $\delta_{\mathrm{H}} 2.91(1 \mathrm{H}, \mathrm{d}, J=2.0 \mathrm{~Hz}, \mathrm{H}-3), 2.98(1 \mathrm{H}, \mathrm{d}$, $J=2.0 \mathrm{~Hz}, \mathrm{H}-3 "), 3.82\left(3 \mathrm{H}, \mathrm{s}, \mathrm{OCH}_{3}\right), 5.32(1 \mathrm{H}, \mathrm{d}, J=2.0 \mathrm{~Hz}, \mathrm{H}-2), 5.37$ (1H, d, $\left.J=2.0 \mathrm{~Hz}, \mathrm{H}-2 "\right), 5.75$ (2H, d, $J=0.5$ Hz, H-6, H-6"), 5.88 (2H, d, $J=0.5$ Hz, H-8, H-8"), 6.63 7.04 (8H, m, H-Ar). HR-ESI-MS: $\mathrm{m} / \mathrm{z} 557.1448[\mathrm{M}+\mathrm{H}]^{+}$. Spectral data were in accordance with those reported in the literature [8], which confirmed that the isolated compound $\mathbf{3}$ was sikokianin A.

\section{Conclusions}

In conclusion, one new biflavanone, 5,5',7,7'-tetrahydroxy-2-(4-hydroxyphenyl)-2'-(4-methoxyphenyl)-[3,3'-bichroman]-4,4'-dione (1), together with two known compounds, sikokianin B (2) and sikokianin A (3) was isolated from the EtOH extract of the roots of Wikstroemia indica.

\section{Acknowledgements}

This material is based upon work funded by Zhejiang Provincial Natural Science Foundation of China (LQ12H30003, LQ12H31001), Foundation of Qianjiang Talents (QJD1002012), Science Research Foundation of Zhejiang Health Bureau (2012KYA068).

\section{References and Notes}

1. Ko, F.N.; Chang, Y.L.; Kuo, Y.H.; Lin, Y.L.; Teng, C.M. Daphnoretin, a new protein kinase C activator isolated from Wikstroemia indica C. A. Mey. Biochem. J. 1993, 295, 321-327.

2. Lee, K.H.; Tagahara, K.; Suzuki, H.; Wu, R.Y.; Haruna, H.; Hall, I.H.; Huang, H.C.; Ito, K.; Iida, T.; Lai, J.S. Antitumor agents. 49 tricin, kaempferol-3-beta-D-glucopyranoside and (+)nortrachelogenin, antileukemic principles from Wikstroemia indica. J. Nat. Prod. 1981, 44, 530-535.

3. Hu, K.; Kobayashi, H.; Dong, A.; Iwasaki, S.; Yao, X. Antifungal, antimitotic and anti-HIV-1 agents from the roots of Wikstroemia indica. Planta Med. 2000, 66, 564-567.

4. Nunome, S.; Ishiyama, A.; Kobayashi, M.; Otoguro, K.; Kiyohara, H.; Yamada, H.; Omura, S. In vitro antimalarial activity of biflavonoids from Wikstroemia indica. Planta Med. 2004, 70, 76-78.

5. Wang, L.Y.; Unehara, T.; Kitanaka, S. Anti-inflammatory activity of new guaiane type sesquiterpene from Wikstroemia indica. Chem. Pharm. Bull. 2005, 53, 137-139.

6. Huang, W.H.; Zhang, X.L.; Wang, Y.F.; Ye, W.C.; Ooi, V.E.C.; Chung, H.Y.; Li, Y.L. Antiviral biflavonoids from radix Wikstroemiae (Liaogewanggen). Chin. Med. 2010, 5, 23. 
7. Ho, W.S.; Xue, J.Y.; Sun, S.S.M.; Ooi, V.E.C.; Li, Y.L. Antiviral activity of daphnoretin isolated from Wikstroemia indica. Phytother. Res. 2010, 24, 657-661.

8. Niwa, M.; Jiang, P.F.; Hirata, Y. Two new C-3/C-3"-biflavanones from Wikstroemia sikokiana. Chem. Pharm. Bull. 1986, 34, 3631-3634.

9. Chen, Y.; Fu, W.W.; Sun, L.X.; Wang, Q.; Qi, W.; Yu, H. A new coumarin from Wikstroemia indica (L.) C. A. Mey. Chin. Chem. Lett. 2009, 20, 592-594.

10. Li, J.; Zhao, W.; Hu, J.L.; Cao, X.; Yang, J.; Li, X.R. A new C-3/C-3"-biflavanone from the roots of Stellera chamaejasme L. Molecules 2011, 16, 6465-6469.

11. Castro, O.; Lopez, J.; Vergara, A. Isoflavans and a Stilbene from Wood of the Decay-Resistant Tropical Tree Diphysa robinioides. J. Nat. Prod. 1986, 49, 680-683.

12. Zeng, Y.Q.; Recio, M.C.; Máñez, S.; Giner, R.M.; Cerdá-Nicolás, M.; Ríos, J.L. Isolation of two triterpenoids and a biflavanone with anti-inflammatory activity from Schinus molle fruits. Planta Med. 2003, 69, 893-898.

13. Liu, W.K.; Cheung, F.W.K.; Liu, B.P.L.; Li, C.M.; Ye, W.C.; Che, C.T. Involvement of p21 and FasL in Induction of Cell Cycle Arrest and Apoptosis by Neochamaejasmin A in Human Prostate LNCaP Cancer Cells. J. Nat. Prod. 2008, 71, 842-846.

14. Tian, Q.H.; Li, J.; Xie, X.; Sun, M.L.; Sang, H.R.; Zhou, C.H.; An, T.Y.; Hu, L.H.; Ye, R.D.; Wang, M.W. Stereospecific Induction of Nuclear Factor- $\kappa \mathrm{B}$ Activation by Isochamaejasmin. Mol. Pharmacol. 2005, 68, 1534-1542.

Sample Availability: Contact the authors.

(C) 2012 by the authors; licensee MDPI, Basel, Switzerland. This article is an open access article distributed under the terms and conditions of the Creative Commons Attribution license (http://creativecommons.org/licenses/by/3.0/). 